\title{
Meslek Yüksekokulu Öğrencilerinin Yaşlanma ve Yaşlılığa Yönelik Tutumlarının Belirlenmesi ${ }^{1}$
}

\author{
Azime ARISOY ${ }^{1 *}(\mathbb{D})$, Özgür ÖNAL ${ }^{2}$ \\ ${ }^{1}$ Asst. Prof. Dr., Burdur Mehmet Akif Esoy University, Çavdır Vocational School, Social Services and \\ Counseling, Burdur, Turkey \\ ${ }^{2}$ Assoc. Prof. Dr., , Süleyman Demirel University, Faculty of Medicine, Public Health Department, Isparta, \\ Turkey
}

Geliş Tarihi/Received: 18.04.2021

Kabul Tarihi/Accepted: 26.05.2021
Doi: 10.31200/makuubd.919978

Araştırma Makalesi/Research Article

\section{ÖZET}

Bu çalışmanın amacı; meslek yüksekokulu öğrencilerinin yaşlanma ve yaşlılığa yönelik tutumlarının ve tutumlarını etkileyen faktörlerin incelenmesi, ayrıca; sosyal hizmet bölümü öğrencilerinin yaşlanma ve yaşlılığa yönelik tutumlarının, aynı meslek yüksekokulunun diğer bölümlerinde eğitim görmekte olan öğrencilerin yaşlanma ve yaşl1llğa yönelik tutumlarından farklılık gösterip göstermediğini araştırmaktır. Tanımlayıcı ve kesitsel tipteki çalışmanın evrenini; Mehmet Akif Ersoy Üniversitesi Çavdır Meslek Yüksekokulunda eğitim görmekte olan 538 öğrenci oluşturmaktadır. Evrenin tamamına ulaşılmak istenmiş olup araştırmaya onay veren 272 öğrenciye (\%50.6) anket uygulanmıştır. Anket formunda, Otrar (2016) tarafindan geliştirilen "Yaşl1lık ve Yaşlanmaya ilişkin Tutum Ölçeği" ayrıca araştırmacılar tarafindan düzenlenen sosyo-demografik bilgilere yer verilmiştir. Öğrencilerin yaşl1lık ve yaşlanmaya ilişkin olumsuz tutum toplam puan ortalaması ve standart sapması 131,92 26,80 (min-max:68213) ve sırasıyla alt ölçek gruplarından "Yaşlılığı Kabullenme Zorluğu", "Sosyal Yıpranma Algısı", "Yaşamla Baş Etme Zorluğu", "Olumsuz İmge" puan ortalama ve standart sapmaları;

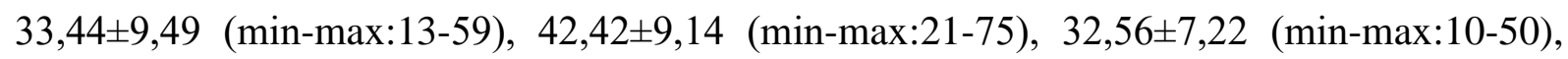

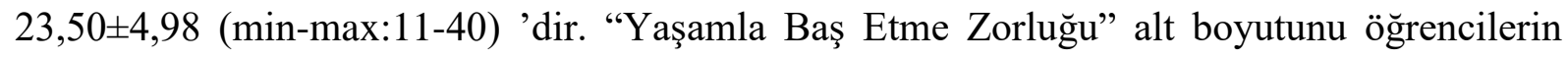
eğitim gördükleri bölüm etkilemektedir $(0,036)$. "Yaşamla Baş Etme Zorluğu" alt boyutunun puanı sosyal hizmetler bölümü öğrencilerinde iş sağlığı ve güvenliği (ISG) ve yaşlı bakım hizmetleri bölümü öğrencilerine göre daha yüksektir. "Yaşlılık ve Yaşlanmaya ilişkin Tutum

\footnotetext{
${ }^{1}$ Mehmet Akif Ersoy Üniversitesi, 07.04.2021 Çarşamba, 2021/04 No'lu Toplantı, GO 2021/172 No'lu Etik kurul İzniyle yapılmıştır.

* Sorumlu yazar/Corresponding author

E-mail/e-ileti: azimearisoy@ hotmail.com
} 
Ölçeği”" nin "Yaşlılığı Kabullenme Zorluğu”, "Sosyal Yıpranma Algısı" ve "Olumsuz İmge” alt boyutları puanlarının ise öğrencilerin eğitim gördükleri bölümlere göre farklılık göstermediği saptanmıştır.

Anahtar kelimeler: Yaşlılık, Yaşlanma, Tutum, Üniversite Öğrencileri.

\section{Determination of Vocational School Students' Attitudes Towards Senility and Aging}

\section{ABSTRACT}

The purpose of this study is to investigate the attitudes and the parameters affecting the attitudes of vocational school students towards aging and senility, also, to examine whether any difference in these attitudes between Welfare Service students and the students from other departments in the same vocational school. The universe of the descriptive and cross-sectional study consists of 538 students training at Mehmet Akif Ersoy University Çavdır Vocational School. It has been intended to reach the whole universe, however, the questionnaire has been able to apply to 272 students (50.6\%) who approved the research. The survey form has included "An Attitude Scale toward Senility and Aging" developed by Otrar (2016), and also sociodemographic information organized by the researchers. The students' average score related to the negative attitude towards senility and aging is $131,92 \pm 26,80$ (min-max:68-213), and also the average scores respectively for the difficulty accepting aging, perception of social attrition, difficulty coping with life, and negative image, are 33,44 $\pm 9,49$ (min-max:13-59), 42,42 $\pm 9,14$

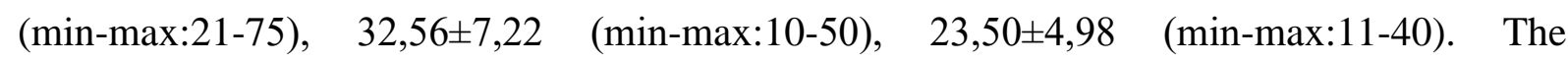
departments where the students trained affect the perception of the difficulty of coping with life $(0,036)$. The score of the students from the Welfare Service department for the difficulty in coping with life is higher than the students from Occupational Health and Safety and elderly care students. It was determined that the students' scores for "Attitude Scale Regarding Aging and Senility" like "Difficulty Accepting Aging", "Perception of Social attrition", and "Negative Image" had no difference according to the departments.

Keywords: Old Age, Aging, Attitude, University Students.

\section{GÍRİŞ}

Dünyada ve ülkemizde yaşlı nüfusu gittikçe artmaktadır. Nüfus yapısındaki bu değişim, yaşlıların yaşadığı sorunlara olan ilginin artmasına neden olmaktadır. Yaşlanmayla birlikte 
bireyler; gelir kaybı, yaşlı yoksulluğu, işsizlik, yaşlı ayrımcılı̆̆ı, yaşlı ihmali, bakım ihtiyacı, yalnızlık, sağlık sorunlarıyla ve sosyal sorunlarla karşı karşıya kalmaktadırlar. Yaşlıların yaşadığı bu sorunlar ve nüfusun hızlı bir şekilde yaşlanması, yaşlılara yönelik uygulanması gereken politikaların önemini de arttırmıştır. Yaşlıların yaşadığı bu sorunlar toplumun yaşlılara ve yaşlılığa yönelik tutumlarıyla yakından ilgilidir. Bu durum; sosyal politika aktörlerini yaşlıların yaşadığı sorunları çözmeye yönelik politikalar üretmeye yöneltmiştir. Söz konusu politikalar ise; toplumun yaşlılara yönelik tutumları ve yaşlılık sürecine ilişkin beklentilerine göre şekillenecektir. Bu bağlamda; toplumun yaşlılara yönelik tutumlarına ilişkin bilimsel araştırmalar önem arz etmektedir.

Literatür taramasında, üniversite öğrencilerinin yaşlılık ve yaşlanmaya ilişkin çok sayıda araştırmanın yapıldığı görülmüştür. Bu çalışmaların lisans programlarında eğitim görmekte olan öğrencileri kapsadığı, meslek yüksekokulu öğrencilerinin katıldığı yaşlılık ve yaşlanmaya yönelik araştırmasının olmadığı görülmüştür. Diğer taraftan; sosyal hizmet bölümü öğrencilerinin yaşı bireylere yönelik tutumları, gelecekte sundukları hizmetin kalitesini etkileyeceği düşünülmektedir. Sosyal hizmet bölümü öğrencilerinin gelecekte icra edecekleri mesleğin hizmet kalitesi bakımından yaşlılara yönelik tutumlarının araştırılması da önem arz etmektedir. Bu bağlamda; meslek yüksekokulu öğrencilerinin ve aynı yüksekokuldaki sosyal hizmet bölümü öğrencilerinin yaşlılara ve yaşlılığa yönelik tutumları araştırılıp karşılaştırılması amaçlanmıştır.

\subsection{Yaşlılık ve Yaşlanma Kavramları}

Yaş; biyolojik, fizyolojik ve kronolojik yaş olmak üzere farklı biçimlerde açıklanmaktadır. Biyolojik yaş; zamanın ilerleyişiyle birlikte hastalık hali söz konusu olmadan meydana gelen fizyolojik olarak işlev değişiklikleridir. Fizyolojik yaş; bireyin yıllar itibariyle yaşanan değişikliklere bağlı olarak davranışsal ve kişisel özelliklerinin değişmesidir. (Güler, 1998, s.105'den aktaran Topgül, 2016, s.375). Kronolojik yaş ise; bireyin doğduğu andan itibaren, içinde bulunduğu ana kadar geçen bütün dönemlerini kapsayan süreç olarak tanımlanmaktadır (Docplayer, 2019).

Bireyin düşünsel kapasite, hareketlilik, fiziksel görünüm, ya da hareketlilik gibi gözlenebilir özelliklerinin aynı yaştaki bireylerle kıyasla belirgin bir şekilde azalması; fonksiyonel yaşl1lık olarak ifade edilmektedir (Güler, 1998, s.105'den aktaran Topgül, 2016, s.375). Yaşlanmadaki fizyolojik düşüş; vücudun hareketlerinde, görme, işitme ve sindirim fonksiyonlarında zayıflama, hafızada azalma gibi bireyin yaşadığı fiziksel değişiklikleri ifade 
eder (Health Dialogue, 2002, s.3). Sosyal yaşlılık ise; sosyal özelliklere ve kültürel duruma göre toplumdan topluma ve kültürden kültüre değișen yaşlılık tanımıdır (Güler, 1998, s.105).

Yaşlanma, büyük ölçüde insan kontrolünün ötesinde, kendi dinamiğine sahip biyolojik bir gerçekliktir. Çoğu gelişmiş ülkede genel olarak emeklilik yaşına rastlayan 60 veya 65 yaşının yaşlılığın başlangıcı olarak belirlenmiştir. $\mathrm{Bu}$ nedenle gelişmiş ülkelerde yaşlanma sürecinde kronolojik yaş çok önemli bir rol oynamaktadır. Bununla birlikte, her toplumun kendine özgü yaşlılık algısı vardır (Gormen, 1999, s.7). Geleneksel toplum yapısına sahip olan birçok ülkede ise, kronolojik yaşın yaşlılık anlamında çok az önemi vardır ya da hiç önemi yoktur. Kronolojik yaştan ziyade asıl önemli olan; bireylerin yaşamlarında meydana gelen bilişsel ve fiziksel dönüşümleri nasıl anlamlandırdıklarıdır (Sarıipek \& Çalhan, 2016, s.88). Geleneksel toplumlarda yaşlı bireylerin yaşam tecrübeleri ve deneyimleri hem toplum hem de aileleri için önemlidir (Topgül, 2016, s.375). Bazı durumlarda, yaşlılığın tanımlanmasında önemli olan kıstas; fiziksel gerilemeye eşlik eden işgücü piyasasına aktif katılımın azalmasıyla birlikte yaşlı bireylerin toplumsal rollerindeki kayıptır. Dolayısıyla, gelişmiş dünyada yaşam evrelerini belirleyen kronolojik kilometre taşlarının aksine, geleneksel toplum yapısına sahip olan birçok ülkede; yaşlılığın bireyin artık topluma aktif katkısının mümkün olmadığı noktada başladığı görülmektedir (Gormen, 1999, s.7).

Dünya Sağlık Örgütüne (WHO) göre; yaşl11ık, bireyin kontrolü dışında meydana gelen ve çevresel faktörlere uyum sağlayabilme yeteneğinde azalma yaşanan biyolojik bir dönemdir. Çoğu gelişmiş ülke 65 yaşı 'yaşlı' olarak kabul etmektedir. Yaşlılık dönemi; genç yaşlılık dönemi, ileri yaşl1lık dönemi ve çok ileri yaşlılık dönemi olmak üzere üç gruba ayrılmaktadır (Saripek \& Çalhan, 2016, ss.78-90; Gökçek Karaca, 2019, ss.255-274). Gelişmiş ve gelişmekte olan ülkelerin sosyal güvenlik sistemlerindeki sıkıntılar nedeni ile emeklilik yaşının 60 ve sonrasında olduğu göz önüne alındığında, 60 yaşın emek piyasasından çekilme yaşı olarak değerlendirilmektedir. Modern tanımda yaşlılık; bireyin çalışma yaşamında aktif olarak yer aldığg dönemini tamamlayarak, biriktirimleriyle ya da sosyal güvence sisteminin katkısıyla yaşadığı dönemin adıdır (Güler, 1998, s.105). Genç yaşlılık dönemi, 60-70 yaş aralığındaki bireyleri yani emek piyasasından yaş sebebiyle çekilmenin hemen sonrasına rastgelen dönemdir. İleri yaşlılık dönemi; bireylerin fonksiyonel kayıplarının yaşlılığa kadar geçen yaşam sürelerine oranla daha yoğun yaşandığ $170-80$ yaş aralığıdır. Çok ileri yaşlılık ise, günlük kişisel bakımı ve fizyolojik gereksinimlerini karşılayabilmek için bir başkasının desteğine gereksinim duyan 80 yaş ve üzeri yaşlardır (Maniar \& Mehta, 2017, s.6). 


\subsection{Dünyada ve Türkiye'de Nüfusun Yaşlanması}

Toplam nüfus içinde yaşlı nüfus oranının \%10'u aşması, nüfusun yaşlanmasının bir göstergesidir (Türkiye İstatistik Kurumu [TÜIKI], 2020). 2019 y1lında dünyada 65 yaş ve üzeri 703 milyon kişi iken 2050'de yaşlıların sayısının iki katına çıkarak 1.5 milyara ulaşacağı tahmin edilmektedir. Küresel olarak, 65 yaş ve üstü nüfusun payı 1990'da yüzde 6 iken 2019'da yüzde 9'a yükselmiştir. Bu oranın 2050 yılına kadar yüzde 16'ya çıkacağı tahmin edilmektedir. Yani 2019 verilerine göre dünyadaki her 11 kişiden 1'i 65 yaş üzeri iken 2050 yllında dünyadaki her altı kişiden biri 65 yaş ve üstü olacaktır. İnsan ömrünün uzaması toplumsal değişikliklerin bir yansımasıdır. Dünyanın birçok yerinde, yaşam süresi gittikçe uzamaktadır. Küresel olarak, 2015-2020'de 65 yaşında olan bir kişi ortalama 17 y1l daha yaşamayı bekleyebilmektedir. 65 yaşında sabit bir "yaşlılık" eşiği ile kronolojik yaşa (doğumdan itibaren içinde bulunulan ana kadar geçen yıllar) dayanan nüfus yaşlanmasına ilişkin geleneksel göstergeler, nüfusun dünyanın tüm bölgelerinde daha da yaşlandığını göstermektedir (United Nations [UN], 2019, s.1). Türkiye'de ise, TÜIK verilerine göre toplam nüfusun 2023 yılında \%10,2'si; 2030 yllında $\% 12,9$ 'u; 2040 yılında $\% 16,3$ 'ü; 2060 yılında $\% 22,6$ 'sı ve 2080 y1lında $\% 25,6$ 'sının yaşlı nüfusu olacağı öngörülmektedir (TÜiK, 2019).

Başarılı nüfus yaşlanması; gelişmiş toplumlar için bir başarı öyküsüne dönüşebilmektedir. Tarih boyunca insan yaşamını sınırlayan hastalıklar, yaralanmalar ve erken ölümlere neden olan önlenebilir sağlık sorunları bakımından, tıbbi ilerlemeler ve sosyal gelişmeler sayesinde önemli derecede ilerleme sağlanmıştır (UN, 2019, s.3). Bireylerin beklenen yaşam süresinin artmasında; fiziksel aktiviteye ve sağlıklı beslenmeye önem verilmesi, çalışma koşullarındaki iyileştirmeler, tıp alanındaki gelişmeler, hayatı kolaylaştırıcı teknolojilerin gelişmesi etkili olmaktadır (Kalaycı vd., 2018, s.23; Kalaycı \& Özkul, 2017, s.90110). Sağlık hizmet kalitesinde artışın, teknolojik gelişmelerin hastalıkların tanı ve tedavisinde kullanılmasının, sağlıklı beslenmeye eğilimin artmasının, sporun yaşamın bir parçası haline gelmesinin ve bulaşıcı hastalıklarda mücadelede aşının yaygınlaşmasının toplumsal yansımaları ortaya çıkmıştır. Dünyanın birçok yerinde ölüm oranı azalmakta, bireylerin yaşam süresi beklentisi ve yaşlı nüfusu artmaktadır. Bunun sonucu olarak da sağlık sorunları ve sağlık bakımı ihtiyaçlarının kapsamı büyük ölçüde farklılaşmaktadır (Wallace, 1992, s.39). Küresel yaşlanma süreci sürecinde Türkiye'de, ölüm ve doğurganlık hızlarındaki azalmayla birlikte sağlık alanındaki başarılı gelişmeler, refah düzeyinin, yaşam standardının ve doğuşta beklenen yaşam süresinin artmasıyla nüfusun yaş yapısında "demografik dönüşüm" yaşanmaktadır. 
Türkiye'de yaşlıların toplam nüfus içindeki oranı artış gösterirken; çocuk ve gençlerin toplam nüfus içindeki oranı azalmaktadır (TÜİK, 2020).

\subsection{Yaşlanma Sürecinde Yaşanan Sorunlar}

Doğurganlık ve ölüm oranlarındaki düşüş, çocuk ölüm oranındaki azalma ve artan yaşam beklentisiyle birlikte, demografik değişim; yaşlıların sayısındaki artış olarak gerçekleşmiştir (Lena vd., 2009, s.132). Nüfus yapısındaki bu hızlı değişimin ise; toplumun baş etmesi gereken sağlık sorunları ve karşılanması gereken sağlık hizmetleri üzerinde önemli etkileri vardır. Bu nedenle; yaşlanan nüfus ile halkın karşı karşıya olduğu sorunlarının içeriği önemli derecede değişmektedir. Bu bağlamda nüfus yapısındaki bu değişim, sağlık önlemleri, emekliliğe ilişkin kamu politikası ve nüfusun yaşlı üyelerinin çalışmaya devam etme arzusu, gelecekte yaşam kalitesinin önemli belirleyicileri olacaktır (Wallace, 1992, s.46).

Uzayan yaşam süresi ve yetersiz sağlık bakımı, yaşlı bireylerdeki kendi kendine yetebilme derecesine olumsuz olarak etkilemekte ve bakım problemlerini arttırmaktadır. Yaşlanma sürecinde yaşlı birey; fizyolojik değişimler, vücudun normal işleyişinde azalma, görme, işitme ve hafızada azalma, düzgün yemek yiyememe, yediği yemeği sindirememe ve daha birçok kronik problemle baş etmeye çalışmaktadır. Diğer yandan sosyo-ekonomik durumdaki değişim de emeklilik sonrası bireylerin yaşam tarzlarını olumsuz etkilemektedir. Yaşlanma, biyolojik değişikliklerin ötesinde, emeklilik, daha uygun konutlara taşınma ve arkadaş ve eşlerin ölümü gibi diğer yaşam geçişleriyle de ilişkilidir (WHO, 2020). TÜİK verilerine göre; yaşlı erkek nüfusun \%12,2'sinin, yaşlı kadın nüfusun ise \%49,2'sinin eşinin vefat etmiş olduğu görülmektedir (TÜİK, 2019).

Yaşlı bireyler sosyo- ekonomik sorunların yanında sağlık sorunlarını da yoğun olarak yaşamaktadırlar. Yaşlılarda kronik hastalıklar özellikle de kanserler, kas iskelet sistemi hastalıkları ve kardiyovasküler hastalıklar ölüm nedenleri arasındadır. Yapılan araştırmalarda da kalp hastalıkları ve hipertansiyon yaşlılarda sık görülen hastalıklar olarak saptanmıştır (Ardahan vd., 2015, s.28). Türkiye'de 2018 yılında vefat eden yaşlıların \%14,8 ile solunum sistemi hastalıkları, \%16,5 ile iyi huylu ve kötü huylu tümörler ve \%43,8'i dolaşım sistemi hastalıkları nedeniyle hayatını kaybetmiştir. Alzheimer hastalığından vefat eden yaşlıların oranı 2014 y1lında \%3,9 iken 2018 yılında \%4,6'ya yükselmiştir (TÜİK, 2020).

Yaşlılıkta; işsizlikte artış ve gelirde azalma yaşanmaktadır (Emiroğlu, 1989, s.41). Yaşl1lıkta sosyo-ekonomik durumdaki değişim ve çeşitli sağlık sorunları, bir bireyin yaşam 
biçimini olumsuz etkilemektedir. Yaşı bireyin yaşadığı ekonomik kayıp, maaştan emekli maaşına veya işsizliğe, çocuklara veya akrabalarına ekonomik bağımlılığa yol açan bir değişiklikten kaynaklanmaktadır (Lena vd., 2019, s.131). Yaşlı bağımlılık oranı, çalışma çağındaki her yüz kişiye düşen yaşı birey sayısını ifade etmektedir. TÜİK verilerine göre, Türkiye'de bu oranının 2023 y1lında \%15,2; 2030 yılında \%19,6; 2040 yılında \%25,3; 2060 y1lında \%37,5; 2080 yılında ise \%43,6 olacağı tahmin edilmektedir (TÜİK, 2019).

TÜİK verilerine göre; Türkiye'de 2018 yılında yaşlı nüfusun \%2,5'inin inşaat sektöründe, \%4,7'sinin sanayi sektöründe, \%27,3'ünün hizmet sektöründe, \%65,5'inin de tarım sektöründe istihdam edildiği görülmektedir (TÜİK, 2020). Herhangi bir işte çalışma güvencesi elde edebilen yaşlilar ise çoğunlukla oldukça düşük ücretle çalıştırılmak zorunda kalmaktadırlar. Yaşlılar, gelirlerini arttıracak, yaşam düzeylerini yükseltecek ek iş bulmakta zorluklara karşılaşmaktadırlar (Emiroğlu, 1989, s.41).

Yaşlı birey, sosyal, ekonomik kayıpla birlikte fizyoloik düşüş nedeniyle öz değer duygusunda da düşüş yaşayabilmektedir (Health Dialogue, 2002, s.3). Yaşam süresindeki artış ve kötü sağlık bakımı, yaşlılar arasında engellilik derecesine artmasına neden olmaktadır ve bakım verme sorunu artmaktadır (Lena vd., 2009, s.132). Tüm bu sorunlara toplumun yaşlılık ve yaşlanmaya yönelik olumsuz tutumları da eklenince yaşlı nüfusun sorunlarını şiddetlenmektedir.

\subsection{Yaşlılara Yönelik Tutum}

Sosyo-ekonomik statüdeki değişiklik ve çeşitli sağlık problemleri, bireyin yaşlılık sırasındaki yaşam biçimini olumsuz etkilemektedir (Lena vd., 2019, s.131). Tüm bu sorunlarla baş etmek zorunda kalan yaşlılar; psikolojik, fiziksel, ekonomik ve sosyal bakımdan başkalarının desteğine ihtiyaç duymaya başlamaktadırlar. $\mathrm{Bu}$ durum toplumdaki diğer bireylerin yaşlılık ve yaşlılara yönelik algı ve tutumlarını etkilemektedir (Kalaycı vd., 2018, s.23; Kalaycı \& Özkul, 2017, ss.90-110). Psikolojik, fiziksel ve ekonomik sorunlarla baş etmeye çalışan yaşı bireyler, sosyal izolasyon, yaş ayrımcılığı sosyal sorunlarla da karşılaşabilmektedirler. WHO tarafından yapılan yaşlılara yönelik tutumla ilgili "Dünya Değerler Anketi" nin analizi, yaşlılara yönelik olumsuz ya da yaş ayrımcılığg tutumların yaygın olduğunu göstermektedir. WHO’nün bu araştırmasına katılanların \% 60'1 yaşı insanlara saygı duyulmadığını ifade etmişlerdir. Lena ve diğerlerinin (2009) yaptıkları araştırmaya katılan yaşlı 
bireylerin ise yaklaşı \% 68'i, insanların yaşlılara karşı tutumunun ihmal olduğunu ifade etmişlerdir (Lena vd., 2009, s.131).

Ülkemizde geleneksel ve geniş aile yapısından çekirdek aile yapısına doğru bir dönüşümün yaşanması gibi toplumsal değişiklikler, yaşlılık ve yaşlılara yönelik algı ve tutumları etkilemektedir (Öztek \& Kubilay, 2008'den aktaran Özdemir \& Bilgili, 2014, s.129). Geleneksel toplum yapısında yaşlı birey; bilgelik, saygınlık, otorite gibi özellikler bakımından değerlendirilmektedir (Tezcan, 1982, s.174). Geleneksel toplumlarda yaşlı birey, ailenin etkin bir aktörü durumundadır. Sanayileşmenin artması, kentleşmenin hızlanması, kadınların çalışma hayatında daha fazla yer alması, köyden kente göçlerin yoğunluğu, geniş aile yapısından çekirdek aileye doğru hızlı değişimin yaşanması gibi toplumsal değişimler, yaşlılığa ve yaşlılara yönelik tutumları etkilemektedir (Özdemir \& Bilgili, 2014, s.129). Toplumsal yapıdaki geleneksel yapıdan modern yapıya doğru değişimle birlikte yaşı bireye aile üyeleri tarafindan atfedilen statünün de değişim de beraberinde gelmiştir (Aile ve Sosyal Politikalar Bakanlığı [ASPB], 2011, s.33). Toplumun sosyo-kültürel yapısındaki bu değişikliklerin etkisiyle oluşan, toplumun ve bireylerin yaşl1lık ve yaşlılara yönelik alg1, tutum ve davranışlarındaki farlılaşmalar ise yaşlılara sunulan hizmetlere yansımaktadır (Erci, 2009, s.4151'den aktaran Özdemir \& Bilgili, 2014, s.129).

\subsection{Araştırmanın Amacı}

Bu çalışmanın amacı, meslek yüksekokulu öğrencilerinin yaşlılığa ve yaşlılara yönelik tutumlarını araştırmaktır. Ayrıca; gelecekte dezavantajlı gruplara yönelik hizmetlerin sahadaki emekçileri olan sosyal hizmet bölümü öğrencilerinin ve diğer bölümlerde eğitim görmekte olan öğrencilerin yaşlılık ve yaşlanmaya yönelik tutumlarını belirleyerek meslek yüksekokulundaki diğer bölümlerde eğitim görmekte olan öğrencilerin tutumlarıyla karşılaştırmak amaçlanmıştır.

\subsection{Araştırmanın Önemi}

Dünyada yaşlı nüfusun hızlı bir biçimde artış yaşanması araştırmacıların bu konuya yönelmesine sebep olmuş ve yaşlılık ve yaşlanmayla ilgili araştırmalarda artış olmuştur. Literatür taramasında; yaşlılık ve yaşlanmaya yönelik tutumları konu alan çok sayıda çalışmanın olduğu görülmektedir. Ancak; yapılan çalışmaların lisans öğrencilerinin katılımıyla yapıldı̆̆ı saptanmıştır. 
Sosyal hizmetler meslek yüksekokulu öğrencilerinin lisans tamamlama programlarına devam etmemeleri halinde; "Sosyal Çalışmacı" unvanına sahip olamamaktadırlar. Bu nedenle; bakıma muhtaç durumda olan bireylere (yaşl1, engelli, çocuk) günlük ihtiyaçlarına destek vermek amaciyla hizmet veren sosyal hizmet profesyonelleri olarak istihdam edilebilmektedirler. Sosyal hizmet mensuplarının hizmet sunduğu dezavantajlı (kadın, engelli, yaşlı, çocuk, şehit yakını, gazi, işsiz, yoksul gibi kırılgan) grupların önemli bir kesimi yaşlı bireylerden oluşmaktadır. Gelecekte özenle ve özveriyle hizmet vermesi beklenen bu öğrencilerin yaşlı ve yaşlılığa yönelik tutumlarının hizmet kalitesi bakımından önemli olduğu düşünülmektedir. Bu bağlamda; sosyal hizmet bölümü öğrencilerin yaşlılara ve yaşlılığa yönelik tutumlarının, meslek yüksekokulunun diğer bölümlerindeki öğrencilerinden olumlu yönde farkl1lık göstermesi beklenmektedir.

\section{YÖNTEM}

\subsection{Araştırmanın Örneklemi ve Ölçüm Araçları}

Bu çalışma 2021 yılı Nisan ayı içerisinde çevrim içi olarak yürütülmüştür. Tanımlayıcı ve kesitsel tipteki çalışmanın evrenini; Mehmet Akif Ersoy Üniversitesi Çavdır Meslek Yüksekokulunda eğitim görmekte olan 538 öğrenci oluşturmaktadır. Evrenin tamamına ulaşılmak istenmiş olup araştırmaya onay veren 272 öğrenciye (\%50. 6) çevrimiçi olarak anket uygulanmıştır. Araştırma için gereken verileri toplamak için anket formu kullanılmıştır. $\mathrm{Bu}$ anket formunda ise; Otrar (2016) tarafından geliştirilen "Yaşlılık ve Yaşlanmaya ilişkin Tutum Ölçeği” ayrıca araştırmacılar tarafından düzenlenen sosyo-demografik bilgilere yer verilmiştir.

\subsection{Araştırmanın Hipotezleri}

H0: Farklı yüksekokul bölümü öğrencileri arasında "Yaşlılık ve Yaşlanmaya" yönelik farkl111k mevcuttur.

H1: Farklı yüksekokul bölümü öğrencileri arasında "Yaşlılı̆̆ı Kabullenme Zorluğu” alt boyutunda farkl111k mevcuttur.

H2: Farklı yüksekokul bölümü öğrencileri arasında "Sosyal Yıpranma Algısı” alt boyutunda farkl111k mevcuttur.

H3: Farklı yüksekokul bölümü öğrencileri arasında "Yaşamla Baş Etme Zorluğu” alt boyutunda farklilik mevcuttur. 
H4: Farklı yüksekokul bölümü öğrencileri arasında "Olumsuz İmge” alt boyutunda farkl111k mevcuttur.

Otrar (2016) tarafından geliştirilen ve bu araştırmada kullanılan "Yaşlılık ve Yaşlanmaya İlişskin Tutum Ölçeği” (YYİTÖ), 5'li likert tipte, 45 sorudan oluşmaktadır. YYİTÖ, dört alt boyuttan oluşmaktadır. Bu alt boyutlardan; Yaşlılığı Kabullenme Zorluğu (YKZ) alt boyutunda 12 soru, Sosyal Yıpranma Algısı (SYA) alt boyutunda 15 soru, Yaşamla Başetme Zorluğu (YBZ) alt boyutunda 10 soru ve Olumsuz İmge (Oİ) alt boyutunda ise 8 soru bulunmaktadır. Ölçekte yer alan maddelere (ters maddeler hariç); kesinlikle katılmıyorum:1 puan, katılmıyorum:2 puan, kararsızım: 3 puan, katılıyorum:4 puan, kesinlikle katıliyorum:5 puan verilmiştir. Ölçekte yer alan ters maddeler ise; (5-4-3-2-1) olarak puanlandırılmıştır. Her bir katılımcının Ölçekten alabileceği en düşük ve en yüksek puan aralı̆̆ı; 45-215' dir.

Verilerin değerlendirilmesinde SPPS 25.0 paket programı kullanılmıştır. İsimsel veriler n (\%), ölçümsel veriler ortalama ve standart sapma ile gösterilmiştir. Normal dağılıma uygunluk Kolmogorov Smirnov testi ile incelenmiştir. Parametrik koşullarda independent samples t test ve one way ANOVA testi, parametrik olmayan koşullarda Mann Whitney U ve Kruskall Wallis T testi uygulanmıştır. $\mathrm{P}<0,05$ istatistiksel açıdan anlamlı olarak kabul edilmiştir.

Otrar'ın (2016) çalışmasında; güvenirlik düzeyleri (Cronbach alpha değeri) ölçek toplamı: 0.97 olarak saptanmıştır. Ölçek alt boyutlarında ise; "Yaşlılığı Kabullenme Zorluğu" için Cronbach alpha değeri:0.93, "Sosyal Yıpranma Algısı” için Cronbach alpha değeri:0.93, "Yaşamla Baş Etme Zorluğu" için Cronbach alpha değeri:0.91 ve "olumsuz imge" için Cronbach alpha değeri: 0.90 olarak tespit edilmiştir.

Bu çalışmada ise güvenirlik değerleri (Cronbach alpha değerleri) ölçek toplamı:0,924, "Yaşl11ığ1 Kabullenme Zorluğu”:0,837, “Sosyal Yıpranma Algısı": 0,778, "Yaşamla Baş Etme Zorluğu”:0,790, “Olumsuz İmge": 0,674 olduğu tespit edilmiştir. Bu değerler doğrultusunda genel olarak ölçeğin alt gruplarıyla birlikte güvenilir olduğu düşünülmektedir (İslamoğlu ve Alnıaçık, 2014: 283).

\subsection{Araştırmada Varsayımlar}

Araştırmaya katılanların soruları anlayarak, içtenlikle cevapladıkları varsayılmaktadır. Ayrıca araştırtmada örneklemin evreni temsil ettiği, kullanılan ölçeğin de araştırmanın amacına uygun olduğu varsayılmaktadır. 


\subsection{Araştırmanın Kısıtlılıkları}

Araştırıma grubunun nispeten homojen olması (yaş grubu açısından, aynı ilçede eğitim görmeleri, öğrencilerin bulundukları bölümlerinin birbirine yakın olması, yükseköğretime geçiş puanlarının benzer olması ) gruplar arası tutum farkı oluşmasını etkilemiş olabilir.

\section{BULGULAR}

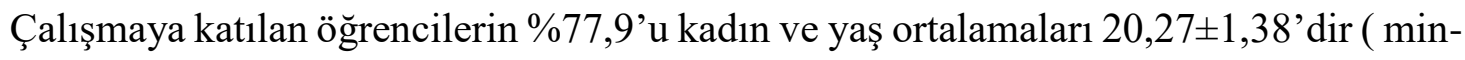
max:18-27). Öğrencilerin yaklaşık olarak yarısı 1 sınıfta ve diğer yarısı da 2. sınıfta eğitim görmektedir. Öğrencilerin büyük çoğunluğu sosyal hizmetler $(\% 59,2)$ ve bilgisayar programlama $(\% 28,3)$ bölümünde okumaktadırlar. Ailelerinin sosyal güvencesi olarak \%60'a yakını SSK'lı olduklarını bildirmişlerdir. Öğrencilerin yaklaşık olarak \%65'i ailelerinin gelir durumunu 1300-3499 TL arası olarak belirtmişlerdir ve \%25'inin evinde yaşlı birey vardır (Tablo 1-2).

Öğrencilerin yaşlanmaya ilişkin olumsuz tutum toplam puan ortalaması ve standart sapması 131,92 $\pm 26,80$ (min-max:68-213) ve sirasıyla alt ölçek gruplarından yaşl1lı̆̆ kabullenme zorluğu, sosyal yıpranma algısı, yaşamla baş etme zorluğu, olumsuz imge puan

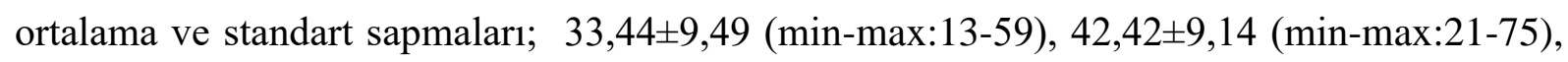

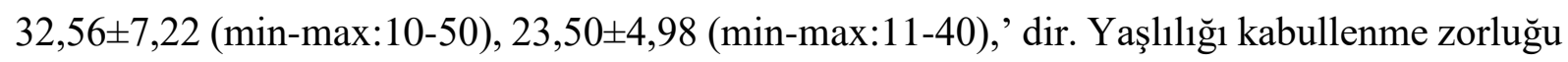
kadınlarda erkeklere göre daha yüksek olmasına rağmen bu fark istatistiksel açıdan anlamsızdır (p:0,069), yaşl1lık olumsuz toplam puan ve diğer alt gruplar cinsiyet ve yaş açısından benzerdir. Yaşamla baş etme puanı da 2 sınıftaki öğrencilerde 1 sınıftaki öğrencilere göre daha yüksek olmasına rağmen bu fark istatistiksel açıdan anlamsızdır $(0,061)$. Yaşlılık olumsuz toplam puan ve diğer alt gruplar öğrencilerin eğitim gördükleri sınıf açısından benzerdir. Yaşamla baş etme zorluğu alt grubunu öğrencilerin bölümü etkilemektedir $(0,036)$. Yaşamla baş etme zorluğu puanı sosyal bilimler bölümü öğrencilerinde İSG (İş Sağlığı ve Güvenliği) ve yaşlı bakım hizmetleri öğrencilerine göre daha yüksektir (Tablo 1). 
Tablo 1. Öğrencilerin cinsiyet-yaş-öğrenim gördükleri sınıf ve bölüme göre yaşlılık ve yaşlanmaya yönelik tutum

\begin{tabular}{|c|c|c|c|c|c|c|c|}
\hline & & n $(\%)$ & $\begin{array}{l}\text { Yaşlılığı } \\
\text { Kabullenme } \\
\text { Zorluğu } \\
\text { ort } \pm \text { SD } \\
\text { (p) }\end{array}$ & $\begin{array}{l}\text { Sosyal } \\
\text { Yıpranma } \\
\text { Algisı, } \\
\text { ort } \pm \text { SD } \\
\text { (p) }\end{array}$ & $\begin{array}{l}\text { Yaşamla Baş } \\
\text { etme Zorluğu, } \\
\text { ort } \pm \text { SD } \\
\text { (p) }\end{array}$ & $\begin{array}{l}\text { Olumsuz } \\
\text { İmge } \\
\text { ort } \pm \text { SD } \\
\text { (p) }\end{array}$ & $\begin{array}{l}\text { Toplam } \\
\text { Olumsuz Puan } \\
\text { ort } \pm \text { SD } \\
\text { (p) }\end{array}$ \\
\hline \multirow[t]{2}{*}{ Cinsiyet } & Kadın & $212(77,9)$ & $34,02 \pm 9,40$ & $42,84 \pm 9,12$ & $32,67 \pm 7,29$ & $23,42 \pm 4,99$ & $132,96 \pm 27,50$ \\
\hline & Erkek & $60(22,1)$ & $\begin{array}{l}31,40 \pm 9,60 \\
(0,059)\end{array}$ & $\begin{array}{l}40,90 \pm 9,13 \\
(0,146)\end{array}$ & $\begin{array}{l}32,15 \pm 7,01 \\
(0,620)\end{array}$ & $\begin{array}{l}23,78 \pm 4,97 \\
(0,613)\end{array}$ & $\begin{array}{l}128,23 \pm 24,06 \\
(0,228)\end{array}$ \\
\hline \multirow[t]{6}{*}{ Yaş } & 18 & $17(6,3)$ & $34,06 \pm 10,86$ & $39,94 \pm 7,62$ & $33,24 \pm 5,46$ & $23,59 \pm 4,27$ & $130,82 \pm 23,95$ \\
\hline & 19 & $59(21,7)$ & $33,63 \pm 9,51$ & $41,90 \pm 9,12$ & $32,56 \pm 6,50$ & $23,42 \pm 4,77$ & $131,51 \pm 25,48$ \\
\hline & 20 & $94(34,6)$ & $33,00 \pm 8,31$ & $42,46 \pm 8,61$ & $31,83 \pm 6,33$ & $23,56 \pm 4,74$ & $130,85 \pm 24,19$ \\
\hline & 21 & $66(24,3)$ & $33,18 \pm 10,06$ & $42,94 \pm 10,43$ & $33,11 \pm 8,72$ & $23,48 \pm 5,06$ & $132,71 \pm 31,16$ \\
\hline & 22 ve üstü & $36(13,2)$ & $34,47 \pm 10,96$ & $43,36 \pm 8,86$ & $33,14 \pm 8,32$ & $23,47 \pm 6,22$ & $134,44 \pm 29,23$ \\
\hline & & & 0,943 & 0,731 & 0,789 & 0,999 & 0,967 \\
\hline \multirow[t]{3}{*}{ Sinıf } & 1 & $137(50,4)$ & $32,81 \pm 9,03$ & $41,82 \pm 9,23$ & $31,74 \pm 7,05$ & $23,49 \pm 4,96$ & $129,86 \pm 26,71$ \\
\hline & 2 & $135(49,6)$ & $34,08 \pm 9,92$ & $43,02 \pm 9,04$ & $33,39 \pm 7,32$ & $23,52 \pm 5,02$ & $134,01 \pm 26,83$ \\
\hline & & & $(0,270)$ & $(0,278)$ & $(0,061)$ & $(0,961)$ & $(0,203)$ \\
\hline \multirow[t]{5}{*}{ Bölüm } & $\begin{array}{l}\text { Sosyal } \\
\text { Hizmetler }\end{array}$ & $161(59,2)$ & $34,42 \pm 9,41$ & $43,16 \pm 8,70$ & $33,40 \pm 7,11$ & $23,52 \pm 4,99$ & $134,50 \pm 26,50$ \\
\hline & Bilgisayar Pr. & $7(2,6)$ & $26,71 \pm 9,55$ & $39,71 \pm 5,47$ & $35,57 \pm 6,48$ & $26,57 \pm 3,36$ & $128,57 \pm 19,31$ \\
\hline & İSG & $77(28,3)$ & $32,86 \pm 9,79$ & $41,81 \pm 10,55$ & $31,34 \pm 7,08$ & $23,57 \pm 5,23$ & $129,57 \pm 28,12$ \\
\hline & $\begin{array}{l}\text { Yaşlı Bakım } \\
\text { H. }\end{array}$ & $27(9,9)$ & $31,04 \pm 8,23$ & $40,41 \pm 7,86$ & $30,22 \pm 7,68$ & $22,41 \pm 4,35$ & $124,07 \pm 25,35$ \\
\hline & & & 0,064 & 0,345 & $0,036^{*}$ & 0,265 & 0,212 \\
\hline Toplam & & $272(100,0)$ & $33,44 \pm 9,49$ & $42,42 \pm 9,14$ & $32,56 \pm 7,22$ & $23,50 \pm 4,98$ & $131,92 \pm 26,80$ \\
\hline
\end{tabular}

Anlamlılığı yaratan faktör sosyal hizmetler bölümündeki öğrencilerin "Yaşamla Baş etme Zorluğu" puanlarının, İSG ve yaşlı bakım hizmetleri öğrencilerine göre puanlarının daha yüksek olmasıdır.

Tablo 2. Öğrencilerin ailelerinin sosyal güvencesi-gelir durumları-evde yaşlı varlığına göre yaşlılık ve yaşlanmaya yönelik tutum

\begin{tabular}{|c|c|c|c|c|c|c|c|}
\hline & & n $(\%)$ & $\begin{array}{l}\text { Yaşlılığı } \\
\text { Kabullenme } \\
\text { Zorluğu } \\
\text { ort } \pm \text { SD } \\
\text { (p) }\end{array}$ & $\begin{array}{l}\text { Sosyal } \\
\text { Yıpranma } \\
\text { Algısı, } \\
\text { ort } \pm \text { SD } \\
\text { (p) }\end{array}$ & $\begin{array}{l}\text { Yaşamla } \\
\text { Başetme } \\
\text { Zorluğu, } \\
\text { ort } \pm \text { SD } \\
\text { (p) }\end{array}$ & $\begin{array}{l}\text { Olumsuz } \\
\text { İmge } \\
\text { ort } \pm \text { SD } \\
\text { (p) }\end{array}$ & $\begin{array}{l}\text { Toplam } \\
\text { Olumsuz Puan } \\
\text { ort } \pm \text { SD } \\
\text { (p) }\end{array}$ \\
\hline \multirow[t]{5}{*}{$\begin{array}{l}\text { Sosyal } \\
\text { güvence }\end{array}$} & SSK & $\begin{array}{l}160 \\
(58,8)\end{array}$ & $33,39 \pm 9,20$ & $41,46 \pm 9,39$ & $32,23 \pm 7,00$ & $23,34 \pm 5,15$ & $130,43 \pm 26,54$ \\
\hline & $\begin{array}{l}\text { Emekli } \\
\text { Sandığ1 }\end{array}$ & $18(6,6)$ & $36,06 \pm 9,80$ & $46,39 \pm 11,15$ & $33,94 \pm 8,03$ & $24,56 \pm 5,03$ & $140,94 \pm 31,22$ \\
\hline & Bağ kur & $44(16,2)$ & $32,84 \pm 10,14$ & $43,45 \pm 8,46$ & $32,82 \pm 7,90$ & $23,73 \pm 4,93$ & $132,84 \pm 27,84$ \\
\hline & GSS & $50(18,4)$ & $33,18 \pm 9,83$ & $43,12 \pm 7,75$ & $32,88 \pm 7,11$ & $23,46 \pm 4,55$ & $132,64 \pm 25,10$ \\
\hline & & & 0,665 & 0,111 & 0,767 & 0,785 & 0,455 \\
\hline \multirow[t]{6}{*}{ Gelir } & $0-1299$ & $34(12,5)$ & $33,59 \pm 7,28$ & $43,00 \pm 8,02$ & $31,47 \pm 6,31$ & $22,94 \pm 4,74$ & $131,00 \pm 21,00$ \\
\hline & $1300-2499$ & $93(34,2)$ & $33,61 \pm 10,16$ & $43,51 \pm 8,72$ & $33,66 \pm 7,21$ & $24,40 \pm 5,03$ & $135,17 \pm 27,80$ \\
\hline & $2500-3499$ & $80(29,4)$ & $33,43 \pm 9,66$ & $42,90 \pm 10,39$ & $32,84 \pm 7,60$ & $23,44 \pm 5,04$ & $132,60 \pm 29,75$ \\
\hline & $3500-4499$ & $33(12,1)$ & $34,48 \pm 9,07$ & $41,73 \pm 9,34$ & $32,88 \pm 6,55$ & $23,00 \pm 5,61$ & $132,09 \pm 25,92$ \\
\hline & $4500+$ & $32(11,8)$ & $31,75 \pm 9,85$ & $38,13 \pm 6,84$ & $29,50 \pm 7,22$ & $22,19 \pm 4,00$ & $121,56 \pm 20,56$ \\
\hline & & & 0,837 & 0,062 & 0,064 & 0,198 & 0,182 \\
\hline \multirow{3}{*}{$\begin{array}{l}\text { Yaşlı var } \\
\text { mı }\end{array}$} & Var & $68(25,0)$ & $32,78 \pm 10,39$ & $43,49 \pm 11,59$ & $31,62 \pm 8,66$ & $23,68 \pm 5,93$ & $131,56 \pm 33,35$ \\
\hline & Yok & $204(75,0)$ & $33,66 \pm 9,19$ & $42,06 \pm 8,17$ & $32,87 \pm 6,66$ & $23,45 \pm 4,64$ & $132,04 \pm 24,33$ \\
\hline & & & $(0,508)$ & $(0,266)$ & $(0,215)$ & $(0,742)$ & $(0,898)$ \\
\hline Toplam & & $\begin{array}{l}272 \\
(100,0)\end{array}$ & $33,44 \pm 9,49$ & $42,42 \pm 9,14$ & $32,56 \pm 7,22$ & $23,50 \pm 4,98$ & $131,92 \pm 26,80$ \\
\hline
\end{tabular}


Yaşlılık olumsuz toplam puan ve diğer alt grup tutumları, öğrencilerin ailelerinin sosyal güvencesi, gelir durumlarına göre değişmemektedir. Evde yaşlı varlığı da öğrencilerin bu konudaki tutumlarını etkilememektedir (Tablo 2).

H0 (Farklı yüksekokul bölümü öğrencileri arasında yaşlılık ve yaşlanmaya yönelik tutumlarında farklılık mevcuttur) hipotezi;

H1 (Farklı yüksekokul bölümü öğrencileri arasında "Yaşlılığı Kabullenme Zorluğu” alt boyutunda farklılık mevcuttur) bakımından reddedilmiştir.

H2 (Farkl1 yüksekokul bölümü öğrencileri arasında "Sosyal Yıpranma Algısı" alt boyutunda farklı1ık mevcuttur) bakımından reddedilmiştir.

H3 (Farkl1 yüksekokul bölümü öğrencileri arasında "Yaşamla Baş Etme Zorluğu” alt boyutunda farklılık mevcuttur)bakımından doğrulanmıştır.

H4 "Farklı yüksekokul bölümü öğrencileri arasında "Olumsuz İmge” alt boyutunda farklılık mevcuttur" bakımından reddedilmiştir.

\section{TARTIŞMA VE SONUÇ}

Dünyada ve ülkemizde yaşı nüfusun hızla artmasıyla birlikte yaşanan sosyo-ekonomik sorunlar, çok sayıda araştırmacıyı bu konuda araştırma yapmaya yöneltmiştir (Şahin \& Demirel, 2018, s.1118). Literatür taramasından yaşl1lık dönemi ve yaşl1lara yönelik tutumlarla ilgili çok sayıda çalışma olduğu saptanmıştır:

Erdemir vd. (2011) tarafından; sağlık profesyonelleri yetiştiren Fizyoterapi, Hemşirelik, Beslenme, Spor, Sosyal Hizmetler ve Sağlık Yönetimi Öğrencilerden 594 katılımcıyla Kogan'ın Yaşlılara Yönelik Tutum Ölçeği (KAOP)'un Türkçe geçerlilik çalışması yapılmıştır. Erdemir vd. (2011), geri çeviri tekniği ve iki aşamalı (4 hafta arayla) veri toplama tasarımı kullandıkları çalışmanın sonucunda; KAOPS' un güvenilir ve geçerli olduğunu saptamışlardır.

Otrar (2016) tarafından; 2015 yılında İstanbul İlinde, rastgele örneklem yöntemiyle ulaşılan 18 yaş üstü, 842 kişinin katılımıyla "Yaşlı1ık ve Yaşlanmaya ilişkin Tutum Ölçeği”" adlı çalışmasında; “ölçeğin 18 yaş üstü yetişkinlerin yaşlılara ve yaşlanmaya yönelik tutumları belirlemede geçerli ve güvenilir bir ölçek olarak kullanılabileceğini” saptamıştır.

Özbek Yazıcı vd. (2016) tarafından sağlıkla ilgili bölümlerde (Fizyoterapi, Hemşirelik ve Yaşlı Bakım Bölümü) eğitim almakta olan 528 öğrencinin yaşlılara yönelik tutumlarını 


\section{Arısoy, A. \& Önal, $\ddot{O}$.}

belirlemek amacıyla çalışma yapılmıştır. Özbek Yazıcı vd. (2016); ankete katılanların yaşlılara yönelik olumlu tutuma sahip olduklarını ancak bu olumlu tutumun düşük düzeyde olduğunu tespit etmişlerdir.

Ünalan vd. (2012) tarafından, geriatri merkezinde çalışmakta olan idari personelin ve sağlık hizmeti veren profesyonellerin yaşlı ayrımcılığına yönelik tutum ve davranışlarını belirlenmek ve bu davranışlara etki eden faktörlerin irdelenmesi amacıyla 49 katılımcıyla geriatri merkezi çalışanların yaşlılara yönelik tutumlarını belirlemek amacıyla çalışma yapılmıştır. Ünalan vd. (2012); çalışmanın sonucunda; geriatri merkezi çalışanların yașlılara ve yașlı ayrımcılığına ilişkin tutumlarının olumlu olduğunu tespit etmişlerdir.

Özbek Yazıcı vd. (2015) tarafından; Süleyman Demirel Üniversitesi Sağlık Hizmetleri Meslek Yüksekokulu Yaşlı Bakım Programından 50 öğrencinin katılımıyla öğrencilerinin yaşlı ayrımcılığına ilişkin tutumlarını belirlemek amacıyla çalışma yapılmıştır. Çalışmanın sonucunda; öğrencilerin yaşlı ayrımcılığına yönelik olarak olumlu tutumlara sahip olduklarını saptamışlardır. "Ayrımcılığın önlenmesi ve öğrencilerin olumlu tutumlarını daha fazla geliştirmek için ders içeriklerinde yaşıı ayrımcılığına ilişkin konuların daha fazla vurgulanması yararlı olacaktır" vurgusu yapılmıştır.

Şahin ve Demirel (2018) tarafından; Kırıkkale Üniversitesi ve Hacettepe Üniversitesinin Sosyal Hizmet Bölümü öğrencilerinden 397 kişinin katılımıyla yaşlılık ve yaşlanmaya ilişkin tutumların araştırıldığı çalışma yapılmıştır. Şahin ve Demirel (2018); sosyal hizmet bölümü öğrencilerinin "yaşlılığa ilişkin olumsuz algı ve tutumlarının nispeten yüksek olduğunu" saptamışlardır.

Yaşlılık dönemi ve yaşlılara yönelik tutumlarla ilgili çok sayıda çalışma yapıllmıştır. Ancak bu çalışmalarda kullanılan ölçekler farklılık göstermektedir. Erdemir ve diğerlerinin (2011) “Kogan'ın Yaşlılara Yönelik Tutum Ölçeği (KAOP)'un Türkçe Versiyonunun Geçerliliği Çalışması" nda; katılımcıların yaşlılara yönelik olumlu tutuma sahip olduklarını tespit edilmiştir. Özbek Yazıcı vd. (2016) çalışmada; Kogan'ın Yaşlılara Yönelik Tutum Ölçeğini (KAOP) kullanmışlardır. Çalışmalarının sonucunda ise; ankete katılanların yaşlılara yönelik olumlu tutuma sahip olduklarını ancak düşük düzeyde olduğunu tespit etmişlerdir. Ünalan vd., (2012) yaptıkları çalışmada; "Yaşlı Ayrımcılığı Tutum Ölçeği” (YATÖ) kullanmışlardır. Çalışmalarının sonucunda ise; katılımcıların yaşlılara yönelik olumlu tutuma sahip olduklarını tespit etmişlerdir. Özbek Yazıcı vd. (2015) çalışmasında; "Yaşlı Ayrımcılığı 
Tutum Ölçeği” (YATÖ) kullanılmıştır. Özbek Yazıcı vd. (2015), çalışmanın sonucunda ise; katılımcıların yaşlı ayrımcılığına yönelik olumlu tutuma sahip olduklarını tespit etmişlerdir.

Otrar tarafından hazırlanan "Yaşlılık ve Yaşlanmaya ilişkin Tutum Ölçeği" (YYİTÖ)'den “elde edilen puan genel toplamının yükselmesi, araştırmaya katılan bireylerin yaşlılık ve yaşlanmaya ilişskin olumsuz algı ve tutumlarının yükseldiği anlamına gelmektedir. Katılımcıların genel puan toplamlarının düşmesi ise yaşlılık ve yaşlanmaya ilişkin olumlu algı ve tutumlarının yükseldiği anlamına gelmektedir. Şahin ve Demirel (2018), Otrar tarafından hazırlanan YYİTÖ’yü kullandıkları çalışmada, 397 katılımıının toplam puan ortalamasını; X= 126,4232 olarak, standart sapmayı ise 27,94551 olarak tespit etmiş olup katılımcıların yaşlılık ve yaşlanmaya ilişkin olumsuz algı ve tutumlarının yüksek olduğu sonucuna ulaşmışlardır. Bu çalışmada ise; 272 katılımcıdan elde edilen toplam puan ortalaması; $X=131,92$, standart sapma ise 26,80 olarak tespit edilmiştir. Şahin ve Demirel (2018) çalışmalarında; araştırmaya katılan kız öğrencilerin yaşlandıkça yaşamla baş etme zorluğu yaşanacağına dair algılarının erkek öğrencilere göre daha yüksek olduğunu tespit etmişlerdir. Bu çalışmada ise; araştırmaya katılan öğrencilerin cinsiyetlerine göre anlamlı bir farklılık saptanmamıştır. Şahin ve Demirel (2018) tarafından yapılan çalışmada; araştırmaya katılan öğrencilerin yaşları arttıkça yaşlılık ve yaşlanmaya yönelik olumsuz tutumlarının kullanılan ölçeğin tüm alt boyutlarında arttığı saptanmıştır. Bu çalışmada ise; araştırmaya katılan öğrencilerin yaşlarına göre yaşlılık ve yaşlanmaya yönelik tutumlarında farklılık saptanmamıştır. Araştırmaya katılan öğrencilerin ailelerinin aylık gelir durumuna göre yaşlılık ve yaşlanmaya yönelik tutumlarında; Şahin ve Demirel (2018) tarafından yapılan çalışmada ve bu çalışmada anlamlı bir farklılık olmadığını saptamışlardır.

Bu veriler 1şığında; Mehmet Akif Ersoy Üniversitesi Çavdır Meslek Yüksekokulunda eğitim görmekte olan öğrencilerin yaşlılık ve yaşlanmaya ilişkin olumsuz algı ve tutumlarının yüksek olduğu sonucuna ulaşılmaktadır. Bu çalışmayla tezat çıkan sonuçların kullanılan ölçek farklılığından kaynaklandığı düşünülmektedir. Şahin ve Demirel'in (2018) çalışmalarıyla benzer sonuçlara ulaşılmasının ise; çalışmalara katılan bireylerin benzer demografik özelliklere sahip olması ve aynı ölçeğin kullanılmasından kaynaklandığı düşünülmektedir. Bu bağlamda; yaşlılık ve yaşlanmaya ilişkin tutumlar konusunda yapılacak çalışmalarda aynı örneklem grubunda; KAOP, YATÖ ve YYİTÖ ölçekleri kullanılarak karşılaştırmalı çalışma yapılması önerilmektedir. 
Meslek yüksekokulu sosyal hizmet ve danışmanlık bölümünden mezun olan öğrenciler, lisans tamamlama programlarına devam etmemeleri durumunda "Sosyal Çalışmacı" unvanıyla sahada hizmet veremeyeceklerdir. Ancak; evde bakım, palyatif bakım merkezi gibi günlük ihtiyaçlarını başkasının desteğiyle karşılayabilen yaşlı bireylerin bakımında hizmet verebileceklerdir. Yaşlı bireyle birebir ilgilenecek sosyal hizmet profesyonellerinin yaşl1lık ve yaşlanmaya yönelik tutumları sunulacak hizmetin kalitesini etkileyeceği düşünülmektedir. $\mathrm{Bu}$ bağlamda sosyal hizmet mensuplarının mesleğinin gerektirdiği davranışları profesyonel bir şekilde sergilemeyi öğrenmelerinin gereği ortaya çıkmaktadır. Bu bölümlerde iletişim dersi verilmektedir. İletişim derslerinde "Rol Play" uygulaması yapılarak iletişim becerilerinin arttırılması, "Duygusal Emek" konusunun da detaylı işlenmesinin faydalı olacağı düşünülmektedir.

\section{REFERENCES / KAYNAKLAR}

Ardahan, M., Arabacı, Z., \& Limoncu, G. (2015).Yaşlıların sağlık sorunları ile başetme yöntemleri. Tıbbi Sosyal Hizmet Dergisi, 6, 28-43.

ASPB. (2011). Türkiye'de yaşlılık dönemine ilişkin beklentiler. Ankara.

Docplayer. (2019). Erişim tarihi: 30.11.2020, https://docplayer.biz.tr/109950273-Kronolojik-yas-nedir.html

Emiroğlu, V. (1989). Yaşlılık ve yaşlının sosyal uyumu. Ankara: Başkent.

Erci, B. (2009). Aile sağlığı hemşireliği. İçinde B. Erci (Ed.), Halk sağglı̆̆ hemşireliği (ss.41-51). Ankara: Fırat Matbaacilik.

Erdemir, F., Kav, S., Citak, E. A., Hanoglu, Z., \& Karahan, A. A. (2011). Turkish version of Kogan's attitude toward older people (KAOP) scale: Reliability and validity assessment. Archives of Gerontology and Geriatrics, 52, e162-e165.

Gorman, M. (1999). Development and the rights of older people. In J. Randel et al. (Eds.), The ageing and development report: Poverty, independence and the world's older people (pp. 3-21). London: Earthscan Publications Ltd.

Gökçek Karaca, N. (2019). Uluslararası ilke ve standartlar bağlamında yaşlı hakları ve sosyal hizmet uygulamaları. 9(2), 255-274.

Güler, Ç. (1998). Yaşlılıkta tanımlar ve yaşlılık üzerine söylenenler. Türk Geriatri Dergisi, l(2), 105.

Health Dialogue. (2002). April-June (Issue No. 29).

İslamoğlu, A. H., \& Alnıaçı, Ü. (2014). Sosyal bilimlerde araştırma yöntemleri. İstanbul: Beta Basım Yayım.

Kalaycı, I., \& Özkul, M. (2017). Geleneksel kalabilsem modern olabilsem: Modernleşme sürecinde yaşlılık deneyimleri. Süleyman Demirel Üniversitesi Vizyoner Dergisi, 8(18), 90-110. 
Kalayc1, I., Özbek Yazıcı, S., Özkul, M., \& Helvacı, G. (2018). Sağlık çalışanları ve öğrencilerinin yaşlılara yönelik tutumları: Sistematik derleme. Adnan Menderes Üniversitesi Sağlık Bilimleri Fakültesi Dergisi, 2(1), 2130.

Lena, A., Ashok, K., Padma, M., Kamath, V., \& Kamath, A. (2019). Health and social problems of the elderly: A cross-sectional study in Udupi Taluk, Karnataka. Indian Journal of Community Medicine, 34(2), 131-134.

Maniar, A., \& Mehta, S. (2017). A study on silver workers residing in Vadodara city. Hamburg, Germany: Anchor Academic Publishing.

Müftülera, H. G. (2018). İstanbul'da yaşl1lık ve yaşlılı̆̆ın yapısal değişimi. Yıldız Sosyal Bilimler Enstitüsü Dergisi, 2(1), 58-80.

Otrar, M. (2016). Yaşlılık ve yaşlanmaya ilişkin tutum ölçeği: Geçerlilik ve güvenilirlik çalışması. Sosyoloji Dergisi, 36(2), 527-550.

Özbek Yazıcı, S., Kalaycı, I., Kaya, E., \& Tekin, A. (2015). Yaşlı bakım programı öğrencilerinin yaşlı ayrımcılığına ilişkin tutumları. Yaşlı Sorunları Araştırma Dergisi, 8(2), 77-87.

Özbek Yazıcı S., Kalaycı, I., Kaya, E., \& Tekin, A. (2016). Sağlıkla ilgili bölümlerde okuyan öğrencilerin yaşlılara yönelik tutumları. Gaziantep University Journal of Social Sciences, 15(2), 601-614.

Özdemir, Ö., \& Bilgili, N. (2014). Sağlık hizmetlerinde yaşlı ayrımcılığı. Gülhane Tıp Dergisi, 56, 128-131.

Öztek, Z., \& Kubilay, G. (2008). Toplum să̆lı̆̆ı hemşireliği (3. Baskı). Ankara: Palme Yayıncılık.

Şahin, H., \& Demirel, B. (2018). Sosyal hizmet bölümü öğrencilerinin yaşlılık ve yaşlanmaya ilişkin tutumlarının belirlenmesi. Uluslararası Sosyal Araştırmalar Dergisi, 11(59), 1114-1120.

Tezcan, M. (1982). Toplumsal değişme ve yaşl1lık. Ankara Üniversitesi Ĕ̆itim Fakültesi Dergisi, 15(2), $169-177$.

Topgül, S. (2016). Çalışma yaşamında yaşlı ayrımcılığı mı yaş ayrımcılığı mı? Sosyoloji Dergisi, 36(2), 373-391.

TÜIKK. (2019). İstatistiklerle yaşl1lar, 2018.

TÜİK. (2020). İstatistiklerle yaşlilar, 2019. $\quad$ Erişim $\quad$ tarihi: $\quad$ 03.12.2020, https://data.tuik.gov.tr/Bulten/Index?p=Istatistiklerle-Yaslilar-2019-33712

United Nations- Department of Economic and Social Affairs Population Division. (2019). World population ageing 2019 highlights, United Nations, New York.

Ünalan, D., Soyuer, F., \& Elmalı, F. (2012). Geriatri merkezi çalışanlarında yaşlı tutumunun değerlendirilmesi. Kafkas Tip Bilimleri Dergisi, 2(3), 115-120.

Wallace, R. B. (Ed.) (2008). Wallace/maxcy-rosenau-last, public health \& preventive medicine. The McGraw-Hill Companies.

WHO. (2020). Erişim tarihi: 01.06.2020, https://www.who.int/news-room 